\title{
TANGGUNG JAWAB PELAKU USAHA TERHADAP PENAYANGAN IKLAN NIAGA YANG MENYESATKAN KONSUMEN
}

\author{
Sudjana \\ Fakultas Hukum, Universitas Padjadjaran \\ sdjana@yahoo.com
}

Submitted: 2021-03-02 | Reviewed: 2021-03-11| Accepted: 2021-04-13

How to cite: Sudjana. "Tanggung
Jawab Pelaku Usaha terhadap
Penayangan Iklan Niaga yang
Menyesatkan Konsumen". Dialogia
Iuridica: Jurnal Hukum Bisnis dan
Investasi, Vol. 12, No. 2, (2021) 001-
021.

DOI:

https://doi.org/10.28932/di.v12i2.3488

\begin{abstract}
This study aims to determine the qualifications of misleading commercial advertisements and the responsibilities of business actors including advertisers, advertising agencies and advertising media in connection with the delivery of misleading commercial advertisements. The approach method used in this study is a normative juridical approach using secondary and data analysis was carried out in a qualitative normative. The results showed that the provisions of Article 9 of the law No.8 of 1999 were included false advertising classification, fraudulent advertising types, and deceptive criteria. The provisions of Article 10 and Article 12 of the Company Law are classified as false advertising, fraudulent advertising, straight forwardlie advertising, and misleading advertising criteria. The provisions of Article 13 of the Company Law include the classification of bait and switch advertising, fraudulent advertising, straight forwardlie advertising, and misleading advertising criteria. Article 17 paragraph (1) the law No.8 of 1999 includes the classification of false advertising, types of fraudulent advertising, and criteria for misleading and deceptive advertising.
\end{abstract}


The principle of accountability of business actors according to Article 20 of the Company Law is strict liability and vicarious liability. Meanwhile, in relation to Article, the forms of responsibility are product and contractual liability (Articles 10, 11, 12, 13 and 17 ), or professional liability for advertising agencies and advertising media or both and it does not rule out the possibility of business actors being subject to sanctions. based on the principle of the presumption of liability principle and the form of responsibility for criminal liability.

Keywords: Responsibility, Business actors, Misleading advertisements, Consumers

\section{PENDAHULUAN}

Pembangunan perekonomian nasional pada era globalisasi harus dapat mendukung tumbuhnya dunia usaha sehingga mampu menghasilkan beraneka barang dan/atau jasa yang memiliki kandungan teknologi yang dapat meningkatkan kesejahteraan masyarakat banyak dan sekaligus mendapatkan kepastian atas barang dan/atau jasa yang diperoleh dari perdagangan tanpa mengakibatkan kerugian konsumen. Hal itu berakibat pada pentingnya proses distribusi produk dari pelaku usaha kepada konsumen melalui informasi yang benar berkaitan dengan kepastian atas kualitas dan kuantitas produk.

Pengembangan bisnis atas suatu produk barang atau jasa memerlukan sarana untuk menginformasikan suatu produk agar konsumen mengetahui kualitas produk tersebut sehingga tertarik untuk membelinya. Sarana yang dimaksud adalah advertensi atau iklan yang memiliki fungsi sebagai bagian dari strategi pemasaran, sehingga setiap iklan selalu dibuat sedemikian rupa sehingga dapat menarik perhatian konsumen karena itu berpotensi timbulnya iklan yang menyesatkan padahal Etika Pariwara Indonesia 2020 dan hukum positif Indonesia telah mengatur iklan dalam berbagai ketentuan, diantaranya Undang-Undang Nomor 8 Tahun 1999 Tentang Perlindungan Konsumen (UUPK), Undang-Undang Nomor 32 Tahun 2002 Tentang Penyiaran (UUP), dan Peraturan Pemerintah Nomor 69 Tahun 1999 Tentang Label dan Iklan Pangan.

UUP menyatakan bahwa "Penyiaran diarahkan untuk memberikan informasi yang benar, seimbang, dan bertanggung jawab”. Ketentuan tersebut juga berlaku terhadap penayangan iklan niaga, sehingga setiap iklan niaga yang ditayangkan harus mengandung informasi yang benar (tidak menyesatkan). Namun, UU tersebut tidak secara tegas melarang iklan yang menyesatkan tetapi hanya melarang siaran iklan niaga melakukan: promosi yang dihubungkan dengan ajaran suatu agama, ideologi, pribadi dan/atau kelompok, yang menyinggung perasaan dan/atau merendahkan 
martabat agama lain, ideologi lain, pribadi lain, atau kelompok lain; promosi minuman keras atau sejenisnya dan bahan atau zat adiktif; promosi rokok yang memperagakan wujud rokok; hal-hal yang bertentangan dengan kesusilaan masyarakat dan nilai-nilai agama; dan/atau eksploitasi anak di bawah umur 18 (delapan belas) tahun. Demikian pula, Etika Pariwara Indonesia 2020 tidak secara tegas mengatur iklan yang menyesatkan tetapi mencantum asas iklan dan perikanan harus: Jujur, benar, dan bertanggung jawab; bersaing secara sehat; tidak merendahkan agama, budaya, Negara, dan golongan, serta tidak bertentangan dengan hukum. ${ }^{1}$ Sedangkan PP No. 69 Tahun 1999 mengatur tentang iklan yang menyesatkan tetapi khusus untuk pangan, sebagaimana tercantum dalam Pasal 5 (1) Keterangan dan atau pernyataan tentang pangan dalam Label harus benar dan tidak menyesatkan, baik mengenai tulisan, gambar, atau bentuk apapun lainnya. (2) Setiap orang dilarang memberikan keterangan atau pernyataan tentang pangan yang diperdagangkan melalui, dalam, dan atau dengan Label apabila keterangan atau pernyataan tersebut tidak benar dan atau menyesatkan. Sebagai contoh maraknya berbagai macam produk minuman suplemen membuat para produsen maupun distributor minuman suplemen saling bersaing keras untuk mendapat bagian pasar produk minuman suplemen. Misalnya Krating Daeng, Kuku Bima, Extra Joss, Gatorade, Lipovitan, M-150, Fit-up dan lain-lain. Produk-produk tersebut mengumbar janji energi tambahan yang membuat tubuh lebih bugar dan bertenaga.

Ketentuan khusus (suigeneris) yang mengatur iklan niaga yang menyesatkan belum ada, tetapi diatur secara umum dalam UUPK tetapi, UU tersebut tidak menjelaskan definisi dan kualifikasi iklan niaga yang menyesatkan, hanya mengatur jenis-jenis iklan yang menyesatkan sebagaimana tercantum dalam Pasal 9, 10, 12, 13 dan 17. Karena itu pengaturan tentang jenis-jenis iklan niaga dalam UUPK perlu dikualifikasikan kedalam beberapa kualifikasi iklan yang menyesatkan. Kualifikasi yang dimaksud dalam kajian ini meliputi: klasifikasi, kriteria, dan bentuk iklan yang menyesatkan sehingga merugikan konsumen.

Latar belakang timbulnya iklan niaga yang menyesatkan adalah keinginan pelaku usaha untuk mendapatkan keuntungan maksimal, sehingga memberikan informasi atau promosi secara berlebihan (hiperbola) serta mengklaim produknya memiliki kualitas lebih baik dibandingkan dengan produk yang lain padahal informasinya kerap kali tidak sesuai dengan janji promosi dan berkesan menyesatkan kosumen. Iklan-iklan tersebut sering beredar di berbagai mediamassa, baik cetak maupun elektronik untuk membangun image terhadap produk yang ditawarkan bahkan penyampaian pesan kepada calon konsumennya tersebut sering kali berlebihan ${ }^{2}$ agar tertarik untuk membelinya.

\footnotetext{
${ }^{1}$ Bandingkan dengan Celina Tri Kristiyanti, Hukum Perlindungan Konsumen, Jakarta: Sinar Grafika, 2011, hlm 135. Lihat juga http://e-journal.uajy.ac.id/3445/3/2EM15140.pdf diakses pada tanggal 16 Desember 2020 pukul 20.00WIB.

${ }^{2}$ Nenny Febriyanti, Analisis Yuridis Terhadap Iklan Menyesatkan Pada Produk Multivitamin Dikaitkan Dengan Undang-Undang Perlindungan Konsumen Dan KEPMENKES No: 386/MEN.KES/ SK/IV/1994 (Studi Kasus: Iklan Multivitamin X), Fakultas Hukum Universitas Indonesia, 2018, hlm 3. Lihat juga
} 
Informasi produk melalui iklan niaga yang menyesatkan tidak sesuai dengan kenyataan berpotensi menimbulkan kerugian bagi konsumen, sehingga pentingnya pertanggungjawaban pelaku usaha atas prilaku yang merugikan tersebut. Namun, pelaku usaha periklanan bukan hanya pengiklan tetapi juga biro iklan, dan media iklan maka timbul permasalahan berkaitan dengan iklan niaga yang menyesatkan, siapa pelaku usaha yang harus memikul beban tanggung jawab, bagaimana prinsip dan bentuk tanggung jawabnya.

Berdasarkan hal itu, maka kajian ini mempermasalah tentang larangan bagi Pelaku Usaha terhadap kualifikasi Iklan yang menyesatkan dihubungkan dengan Hak Konsumen dalam Perspektif Hukum Positif Indonesia dan Tanggung Jawab hukum Pelaku Usaha berkaitan dengan Penayangan Iklan yang menyesatkan Konsumen.

Metode penelitian yang digunakan deskriptif analisis melalui pendekatan yuridis normatif, ${ }^{3}$ tentang persoalan-persoalan yang menyangkut tanggung jawab pelau usaha berkaitan dengan iklan niaga yang menyesatkan. Penelaahan dilakukan terhadap data sekunder atau studi kepustakaan yang meliputi bahan hukum primer, sekunder, dan tersier serta teknik analisis data bersifat normatif kualitatif yaitu analisis terhadap kaidah hukum positif, tidak menggunakan angka-angka atau rumus statistik.

\section{PEMBAHASAN}

\section{Larangan bagi Pelaku Usaha terhadap Penayangan Iklan yang menyesatkan dihubungkan dengan Hak Konsumen dalam Perspektif Hukum Positif Indonesia}

UUPK menjelaskan pengertian pelaku usaha yaitu setiap orang perseorangan atau badan usaha, baik yang berbentuk badan hukum maupun bukan badan hukum yang didirikan dan berkedudukan atau melakukan kegiatan dalam wilayah hukum negara Republik Indonesia, baik sendiri maupun bersama-sama melalui perjanjian menyelenggarakan kegiatan usaha dalam berbagai bidang ekonomi. Namun, tidak merinci secara tegas, siapa pelaku usaha periklanan. Menurut A.Z Nasution, apabila berpedoman pada Tata Krama dan Tata Cara Periklanan Indonesia maka yang dimaksud dengan pelaku usaha periklanan itu adalah pengiklan, biro iklan, dan media periklanan. Pengiklan, yaitu perusahaan atau perseorangan (produsen, distributor, supplier) yang mengiklankan suatu produk (barang dan jasa). Biro iklan, adalah perusahaan yang bergerak di bidang biro jasa pembuatan iklan dan berfungsi sebagai pihak yang mempertemukan antara pengiklan dengan media (sarana atau tempat pemasangan/penyiar iklan). Media periklanan adalah media komunikasi massa, yang meliputi baik media cetak (surat kabar, majalah tabloid) maupun media elektronik (televisi, radio).

Iklan adalah sarana bagi konsumen untuk mengetahui barang dan atau jasa yang ditawarkan oleh pelaku usaha yaitu pengiklan, karena konsumen mempunyai hak untuk mendapat informasi dan hak untuk memilih. Pemberitahuan ini dengan menyiarkan

Aghia Khumaesi Suud, “Analisis Perlindungan Hukum Bagi Konsumen Terhadap Iklan Barang atau Jasa Online yang Menyesatkan”, Pandecta, Volume 14. Number 2. December 2019: 73-82, hlm 75.

3 Henni Muchtar, "Analisis Yuridis Normatif Sinkronisasi Peraturan Daerah Dengan Hak Asasi Manusia", Jurnal Humanus, Vol. XIV No.1 Th. 2015, hlm 84. 
pesan atau rangkaian pesan dalam bentuk suara, gambar, atau suara dan gambar atau yang berbentuk grafis, karakter, baik yang bersifat interaktif maupun tidak, yang dapat diterima melalui perangkat penerima siaran. Siaran iklan adalah siaran informasi yang bersifat komersial dan layanan masyarakat tentang tersedianya jasa, barang, dan gagasan yang dapat dimanfaatkan oleh khalayak dengan atau tanpa imbalan kepada lembaga penyiaran yang bersangkutan Siaran iklan niaga adalah siaran iklan komersial yang disiarkan melalui penyiaran radio atau televisi dengan tujuan memperkenalkan, memasyarakatkan, dan/atau mempromosikan barang atau jasa kepada khalayak sasaran untuk mempengaruhi konsumen agar menggunakan produk yang ditawarkan.

Hak konsumen berkaitan dengan penayangan iklan adalah hak atas informasi yang benar, jelas, dan jujur mengenai kondisi dan jaminan barang dan/atau jasa; dan hak untuk mendapatkan kompensasi, ganti rugi dan/atau penggantian, apabila barang dan/atau jasa yang diterima tidak sesuai dengan perjanjian atau tidak sebagaimana mestinya. Di sisi lain, pelaku usaha wajib memberikan informasi yang benar, jelas dan jujur mengenai kondisi dan jaminan barang dan/atau jasa serta memberi penjelasan penggunaan, perbaikan dan pemeliharaan; dan memberi kompensasi, ganti rugi dan/atau penggantian apabila barang yang diterima atau dimanfaatkan tidak sesuai dengan perjanjian. Lebih lanjut, pelaku usaha dilarang memperdagangkan barang yang tidak sesuai dengan janji yang dinyatakan dalam label, etiket, keterangan, iklan atau promosi penjualan barang tersebut.

Pengertian iklan yang menyesatkan tidak secara tegas dijelaskan dalam UUPK, tetapi menyebutkan kriteria atau jenis-jenis iklan yang menyesatkan atau mengelabui. Hal ini sejalan pula dengan FTC yaitu salah satu badan pengawasan periklanan di Amerika Serikat, juga tidak memberikan pengertian dengan tegas mengenai iklan menyesatkan. Hanya dalam The FTC's Deception Policy Statement dijelaskan bahwa (www. FTC.Gov): "An Ad is deceptive if it contains a statement-or omits information - that: 1. is likely to mislead consumers acting reasonably under the circumstances; and 2. is "material" - that is important to a consumer's decision to buy or use the product". Iklan mengandung misrepresentation jika penyataan eksplisit atau implisit bertolak belakang dengan fakta, atau jika informasi penting untuk mencegah terjadinya misleading dalam suatu praktek, klaim, representasi, atau kepercayaan yang reasonable tidak dipaparkan (omission). ${ }^{4}$

Ada 2 (dua) sudut pandang berbeda yang memberikan uraian mengenai iklan yang menyesatkan. Pertama, dari sudut pandang konsumen, iklan yang menyesatkan dipandang sebagai pernyataan atau gambaran atas produk yang menyebabkan konsumen terpedaya oleh janji pelaku usaha dan mengakibatkan kerugian bagi konsumen. Kedua, dari sudut pandang pelaku usaha, iklan yang menyesatkan sebagai perbuatan pelaku

${ }^{4}$ Dedi Harianto, "Standar Penentuan Informasi Iklan Menyesatkan", Jurnal Equality, Vol. 13 No. 1 Februari 2008, hlm 43. 
usaha yang sengaja atau lalai dalam memberikan pernyataan atau gambaran atas produk yang tidak benar, tidak jelas, dan atau tidak jujur. ${ }^{5}$

Klasifikasi iklan yang menyesatkan dapat berupa bait advertising, blind advertising, dan false advertising. ${ }^{6}$ Bait Advertising, adalah suatu iklan yang menarik, tetapi penawaran yang disampaikan tidak jujur untuk menjual produk karena pengiklan tidak bermaksud menjual barang yang diklankan. Tujuannya agar konsumen mengganti membeli barang yang diiklankan dengan barang jualan lainnya yang biasanya lebih mahal atau lebih menguntungkan pengiklan. Blind Avertising, adalah suatu iklan yang cenderung membujuk konsumen untuk berhubungan dengan pengiklan namun tidak menyatakan dengan tujuan utama iklan tersebut untuk menjual barang atau jasa, dan tidak menyatakan dengan identitas pengiklan. False Advertising, adalah jika representasi tentang fakta dalam iklan adalah salah, yang diharapkan untuk membujuk pembelian barang yang diiklankan, dan bujukan pembelian tersebut merugikan pembeli, serta dibuat atas dasar tindakan kecurangan atau penipuan

Kriteria iklan yang menyesatkan apabila merujuk pada perspektif hukum positif di Indonesia adalah pertama, penyesatan informasi yaitu ${ }^{7}$ :

a. Iklan yang mengelabui konsumen (misleading) mengenai kualitas, kuantitas, bahan, kegunaan, harga, tarif, jaminan dan garansi barang dan atau jasa serta pelaku usaha tidak bertanggungjawab sebagaimana dinyatakan dalam iklan.

b. Mendeskripsikan memberikan informasi secara keliru, salah, maupun tidak tepat (deceptive) mengenai barang dan atau jasa.

c. Memberikan gambaran secara tidak lengkap (ommision) mengenai informasi barang dan atau jasa.

d. Hal lain yang dilarang dan melanggar ketentuan hukum yaitu memberikan informasi yang berlebihan (puffery) mengenai kualitas, sifat, kegunaan, kemampuan barang dan/atau jasa dan membuat perbandingan barang dan atau jasa yang menyesatkan konsumen.

Beberapa bentuk iklan yang mengandung unsur penyesatan antara lain : ${ }^{8}$

a. Iklan pancingan (bait and switch advertising). Iklan ini sebenarnya tidak berniat untuk menjual produk yang ditawarkan, melainkan untuk menarik kunjungan konsumen ke tempat usaha tersebut atau menawarkan barang tertentu dengan harga khusus atau janji pemberian hadiah, padahal pelaku usaha tidak berniat melakukan ataupun jika melakukan dalam jumlah yang tidak wajar.

\footnotetext{
5 Taufik H. Simatupang, Aspek Hukum Periklanan dalam Perspektif Perlindungan Konsumen, Citra Aditya Bakti, Bandung, 2014, hlm 12-13-27.

${ }^{6}$ Ahmadi Miru dan Sutarman Yodo, Hukum Perlindungan Konsumen. PT. Raja Grafindo Persada: Jakarta: 2008, hlm 105.

${ }^{7}$ http://repository.untag-sby.ac.id/1560/10/BAB\%20III.pdf diakses pada tanggal 18 Desember 2020 pukul 21.00 WIB.

${ }^{8}$ Taufik H. Simatupang, loc.cit.
} 
b. Iklan menyesatkan (mock-up advertising). Iklan jenis ini biasanya hanya menunjukkan keampuhan suatu produk dengan melalui penggambaran yang berlebihan dengan menggunakan media televisi sehingga menghasilkan efek tayangan yang mengesankan.

Kedua, fakta materil yang dapat mempengaruhi konsumen dalam memutuskan untuk melakukan pembelian. Ketiga, konsumen rasional yaitu konsumen yang dalam memilih atau membeli barang dan/atau jasa, benar-benar didasarkan atas pertimbangan yang matang berdasarkan informasi yang diterimanya melalui iklan. Keempat, pembenaran terhadap klaim iklan yaitu menonjolkan klaim-klaim produk tanpa disertai pembuktian kongkrit, merupakan salah satu bentuk penyesatan informasi yang ditemukan di berbagai media cetak maupun elektronik. ${ }^{9}$

Ketentuan Pasal 9 UUPK "Pelaku usaha (pengiklan) dilarang menawarkan, mempromosikan, mengiklankan suatu barang dan/atau jasa secara tidak benar, dan/atau seolah-olah":

a. barang tersebut telah memenuhi dan/atau memiliki potongan harga, harga khusus, standar mutu tertentu, gaya atau mode tertentu, karakteristik tertentu, sejarah atau guna tertentu;

b. barang tersebut dalam keadaan baik dan/atau baru;

c. barang dan/atau jasa tersebut telah mendapatkan dan/atau memiliki sponsor, persetujuan, perlengkapan tertentu, keuntungan tertentu, ciri-ciri kerja atau aksesori tertentu;

d. barang dan/atau jasa tersebut dibuat oleh perusahaan yang mempunyai sponsor, persetujuan atau afiliasi;

e. barang dan/atau jasa tersebut tersedia;

f. barang tersebut tidak mengandung cacat tersembunyi;

g. barang tersebut merupakan kelengkapan dari barang tertentu;

h. barang tersebut berasal dari daerah tertentu;

i. secara langsung atau tidak langsung merendahkan barang dan/atau jasa lain;

j. menggunakan kata-kata yang berlebihan, seperti aman, tidak berbahaya, tidak mengandung risiko atau efek sampingan tanpa keterangan yang lengkap;

k. menawarkan sesuatu yang mengandung janji yang belum pasti.

Pradopo berpendapat bahwa ada 3 (tiga) tipe iklan yang memperdaya (deceptive advertising), yaitu : ${ }^{10}$

a. Fraudulent advertising, iklan yang tidak dapat dipercaya (straight forwardlie).

\footnotetext{
${ }^{9}$ Dedi Harianto, op.cit, hlm 47.

${ }^{10}$ Adde Riyatna Harahap, Perlindungan Hukum Bagi Konsumen Akibat Iklan Yang Menyesatkan, Skripsi, Fakultas Hukum Universitas Muhammadiyah Sumatera Utara Medan, 2019, hlm 4-5.
} 
b. False advertising, klaim terhadap manfaat produk yang dapat dipenuhi berdasarkan syarat dan ketentuan yang berlaku (under certain conditions), yang tidak dijelaskan secara jelas dalam iklan tersebut.

c. Misleading advertising, iklan ini melibatkan antara klaim dan kepercayaan. Misalnya, memiliki kulit putih merupakan bagian dari kecantikan. Kepercayaan konsumen ini dimanfaatkan pelaku usaha untuk memproduksi pemutih kulit.

Larangan terhadap pelaku usaha sebagaimana tercantum dalam ketentuan Pasal 9 UUPK “...... secara tidak benar, dan/atau seolah-olah...” termasuk kedalam klasifikasi false advertising karena representasi tentang fakta dalam iklan adalah salah, kriteria deceptive yaitu iklan yang dapat memperdaya konsumen karena konsumen akan mengira bahwa iklan tersebut benar padahal "seolah olah" yang bertipe iklan fraudulent advertising yaitu iklan yang tidak dapat dipercaya (straight forwardlie).

Fakta materil yang dapat mempengaruhi konsumen dalam memutuskan untuk melakukan pembelian tercantum dalam Pasal 10 UUPK "Pelaku usaha dalam menawarkan barang dan/atau jasa yang ditujukan untuk diperdagangkan dilarang menawarkan, mempromosikan, mengiklankan atau membuat pernyataan yang tidak benar atau menyesatkan mengenai":

a. harga atau tarif suatu barang dan/atau jasa;

b. kegunaan suatu barang dan/atau jasa;

c. kondisi, tanggungan, jaminan, hak atau ganti rugi atas suatu barang dan/atau jasa;

d. tawaran potongan harga atau hadiah menarik yang ditawarkan;

e. bahaya penggunaan barang dan/atau jasa.

Pasal 12 UUPK: Pelaku usaha dilarang menawarkan, mempromosikan atau mengiklankan suatu barang dan/atau jasa dengan harga atau tarif khusus dalam waktu dan jumlah tertentu, jika pelaku usaha tersebut tidak bermaksud untuk melaksanakannya sesuai dengan waktu dan jumlah yang ditawarkan, dipromosikan, atau diiklankan.

Pasal 10 dan Pasal 12 UUPK merupakan klasifikasi iklan false advertising, bentuk iklan termasuk kriteria iklan yang tidak benar atau menyesatkan (misleading), misalnya menyebutkan adanya sesuatu yang sebenarnya tidak ada, atau menyebutkan tidak adanya sesuatu yang sebenarnya sesuatu itu ada dalam produksi yang diiklankan, tipe iklan fraudulent advertising, iklan yang tidak dapat dipercaya (straight forwardlie).

Pasal 13 ayat (1) UUPK: Pelaku usaha dilarang menawarkan, mempromosikan, atau mengiklankan suatu barang dan/atau jasa dengan menjanjikan pemberian hadiah berupa barang dan/atau jasa lain secara cuma-cuma dengan maksud tidak memberikannya atau memberikan tidak sebagaimana yang dijanjikannya. Pasal 13 ayat (2) UUPK: Pelaku usaha dilarang menawarkan, mempromosikan atau mengiklankan obat, obat tradisional, suplemen makanan, alat kesehatan, dan jasa pelayanan kesehatan dengan menjanjikan pemberian hadiah berupa barang dan/atau jasa lain. Pasal 13 UUPK 
termasuk klasifikasi false advertising karena representasi tentang fakta dalam iklan adalah salah, yang diharapkan untuk membujuk pembelian barang yang diiklankan, dan bujukan pembelian tersebut merugikan pembeli, serta dibuat atas dasar tindakan kecurangan atau penipuan, tipe iklan fraudulent advertising, iklan yang tidak dapat dipercaya (straight forwardlie), bentuk iklan pancingan (bait and switch advertising), dan kriteria iklan yang mengelabui konsumen (misleading).

Pasal 17 ayat (1) UUPK "Berkaitan dengan usaha periklanan, pelaku usaha periklanan dilarang memproduksi iklan yang":

a. mengelabui konsumen mengenai kualitas, kuantitas, bahan, kegunaan dan harga barang dan/atau tarif jasa serta ketepatan waktu penerimaan barang dan/atau jasa;

b. mengelabui jaminan/garansi terhadap barang dan/atau jasa;

c. memuat informasi yang keliru, salah, atau tidak tepat mengenai barang dan/atau jasa;

d. tidak memuat informasi mengenai risiko pemakaian barang dan/atau jasa;

e. mengeksploitasi kejadian dan/atau seseorang tanpa seizin yang berwenang atau persetujuan yang bersangkutan;

f. melanggar etika dan/atau ketentuan peraturan perundang-undangan mengenai periklanan.

Kriteria konsumen yang rasional tercantum ketentuan Pasal 17 ayat (1) huruf a dan b karena konsumen yang dalam memilih atau membeli barang dan/atau jasa yang dibutuhkan, benar-benar didasarkan atas pertimbangan yang matang berdasarkan informasi yang diterimanya melalui iklan tetapi informasi tersebut tidak benar (menyesatkan). Oleh karena itu Pasal 17 ayat (1) UUPK termasuk klasifikasi iklan yang false advertising, kriteria mengelabui konsumen (misleading) dan deceptive karena iklan yang dapat memperdaya konsumen dengan tipe fraudulent advertising iklan yang tidak dapat dipercaya (straight forwardlie).

Kasus yang pernah terjadi adalah Krating Daeng, Kuku Bima, Extra Joss, Gatorade, Lipovitan, M-150, Fit-up dan lain-lain. Produk-produk tersebut mengumbar janji energi tambahan yang membuat tubuh lebih bugar dan bertenaga. ${ }^{11}$ Setelah secara teliti tertera tulisan "3 kali Sehari DITETAPKAN POM SD 051219 991”. Tulisan pada box kemasan serta sachet disusun sedemikian rupa sehingga menghasilkan persepsi ada penetapan dari POM untuk mengkonsumsi 3 kali sehari. Pencantuman tulisan ' 3 kali sehari' diletakkan diatas tulisan 'DITETAPKAN' lalu dibawahnya ada tulisan 'POM SD 051219 991' yang menghasilkan tulisan 'kali Sehari DITETAPKAN POM SD 051 219 991". Tulisan tersebut memberikan kesan POM menetapkan mengkonsumsi 3 kali sehari. Hal ini jelas merupakan menyesatkan karena selain menggunakan badan Negara

\footnotetext{
${ }^{11}$ Herlina Buta-Butar (editor: Widiya buana Slay) Waspadai Iklan Extra Joss yang Menyesatkan, Tribunnews.com, https://www.tribunnews.com/tribunners/2011/06/30/waspadai-iklanextra-joss-yang-menyesatkan, 13 Desember 2020.
} 
demi kepentingan pemilik produk juga menghasilkan pemikiran yang menyimpang. ${ }^{12}$ Contoh lain adalah merebaknya berita bahwa salah satu produk Susu Kental Manis (SKM) kalengan yang ternyata menurut penyelidikan BPOM tidak mengandung Susu murni dan tidak cocok dikonsumsi untuk anak-anak dan balita, melainkan sebagai pelengkap sajian saja. Padahal SKM tersebut merupakan merek terkenal selama puluhan tahun yang sudah familiar di tengah-tengah masyarakat ternyata berbeda dengan kandungan isi aslinya yang dipasarkan sebagai SKM murni. BPOM dalam rilisnya kemudian merekomendasikan kepada produsen produk tersebut untuk segera menghapus iklan terhadap produk Susu Kental Manis dan menarik produknya yang masih dijual bebas di pasaran. ${ }^{13}$

Iklan-iklan yang menyesatkan memerlukan pengawasan aktif lembaga yang berwenang yaitu Komisi Penyiaran Indonesia (KPI) dan struktur vertikalnya di daerahdaerah yang tunduk pada UUP bekerjasama dengan Lembaga Sensor Film (LSF) yang kewenangannya diatur dalam UU Perfilman. UUP mewajibkan semua tayangan non jurnalistik seperti film, promo film dan iklan yang hadir di televisi, mendapatkan STLS (Surat tanda Lolos Sensor) dari lembaga sensor yang berwenang. Apabila dihubungkan dengan fungsi hukum, maka kewajiban tersebut merupakan social control dan rekayasa sosial (social engineering) terhadap pola prilaku dari pelaku usaha dalam menayangkan iklan. Hukum sebagai alat kontrol sosial berarti menetapkan tingkah laku manusia yang menyimpang terhadap aturan hukum, sehingga dapat dikenakan sanksi atau tindakan terhadap pelanggarnya. Karena itu, hukum menetapkan sanksi untuk mengarahkan mengarahkan agar masyarakat berprilaku menurut aturan sehingga terwujud ketertiban dan ketentraman. ${ }^{14}$ Sedangkan hukum sebagai rekayasa sosial ( $a$ tool of social engineering) diperlukan dalam proses perubahan masyarakat untuk mengubah pola-pola tertentu karena sudah tidak cocok lagi dengan kondisi saat itu atau menguatkan prilaku agar sesuai dengan yang diharapkan oleh hukum. ${ }^{15}$

Hukum sebagai social control juga tercermin dari adanya penuntutan pidana dapat dilakukan terhadap pelaku usaha dan/atau pengurusnya. Makna pelaku usaha dalam Pasal 9 dan Pasal 10 UUPK adalah "pengiklan" sedangkan ketentuan Pasal 17 ditujukan untuk " biro iklan". Pelaku usaha yang melanggar ketentuan dalam Pasal 8, Pasal 9, Pasal 10, Pasal 13 ayat (2), Pasal 15, Pasal 17 ayat (1) huruf a, huruf b, huruf c, huruf e, ayat (2), dan Pasal 18 UUPK dipidana dengan pidana penjara paling lama 5 (lima) tahun atau pidana denda paling banyak Rp 2.000.000.000,00 (dua miliar rupiah). Terhadap pelanggaran yang mengakibatkan luka berat, sakit berat, cacat tetap atau kematian diberlakukan ketentuan pidana yang berlaku yaitu sebagaimana diatur dalam

\footnotetext{
12 Ibid.

13 http://download.garuda. ristekdikti.go.id/article.php?article $=16672 \& v a l=5918 \&$ title $=$ Iklan $\% 20$ Menyesat$\% 20$ Deceptive $\% 20$ Advertisement $\% 20 \% 20$ Dalam $\% 20$ Hukum $\% 20$ Perlindungan $\% 20$ Konsumen, diakses 14 Desember 2020.

${ }^{14}$ Bandingkan dengan Ashadi L. Diab, "Peranan Hukum Sebagai Social Control, Social Engineering dan Social Welfare”, Jurnal Al- 'Adl, Vol. 7 No. 2, Juli 2014, hlm 58.

15 Ibid.
} 
KUHPidana (lex generalis) vide Pasal 359 " pidana penjara paling lama lima tahun atau kurunga paling lama satu tahun" dan Pasal 360 ayat (1)" pidana paling lama satu tahun", dan Pasal 360 ayat (2) paling lama sembilan bukan atau kurungan paling lama 6 bulan".

Terhadap sanksi pidana sebagaimana, dapat dijatuhkan hukuman tambahan, berupa:

a. perampasan barang tertentu;

b. pengumuman keputusan hakim;

c. pembayaran ganti rugi;

d. perintah penghentian kegiatan tertentu yang menyebabkan timbulnya kerugian konsumen;

e. kewajiban penarikan barang dari peredaran; atau

f. pencabutan izin usaha

Pidana pada hakekatnya mempunyai dua tujuan utama yaitu untuk mempengaruhi tingkah laku (gedragsbeinvloeding) dan penyelesaian konflik (conflict toplossing). ${ }^{16}$ Untuk mempengaruhi tingkah tersebut dilakukan melalui pengenaan sanksi sebagai kontrol sosial agar pelaku usaha memahami bahwa tindakannya akan memiliki konsekuensi hukum berupa "punishment", sehingga dapat mencegah (preventif) terhadap perbuatan yang akan dilakukannya. Namun, apabila pelaku usaha yang bersangkutan tetap melakukan informasi yang menyesatkan melalui penayangan iklan yang menyesatkan, maka sanksi pidana berfungsi sebagai tindakan yang harus dilakukan (represif). Penyelesaian konflik menggunakan hukum pidana sebagai social engineering merupakan upaya terakhir (ultimum remedium), apabila bidang hukum lainnya tidak dapat menyelesaikan sengketa antar pelaku usaha dan konsumennya.

Menurut teori absolut atau teori pembalasan (relative/vergeldings theorieen) pidana dijatuhkan semata-mata karena orang telah melakukan suatu kejahatan atau tindak pidana (quia peccatum est). Dengan demikian, merupakan akibat mutlak yang harus ada sebagai suatu pembalasan kepada orang yang melakukan kejahatan tersebut. Sedangkan tujuan utama (primair) dari pidana menurut teori ini ialah "untuk memuaskan tuntutan keadilan" (to satisfy the claims of justice). Sedangkan menurut teori relatif atau teori tujuan (utilitarian/doelheorieen), pemidanaan bukanlah untuk memuaskan tuntutan absolut dari keadilan. Pembalasan itu tidak mempunyai nilai, tetapi sebagai sarana untuk melindungi kepentingan masyarakat. Namun dalam perkembangannya pemberian hukuman kepada pelaku tidak hanya dilihat dari kepentingan masyarakat tetapi juga kepada kepentingan pelaku, artinya apabila dibiarkan tanpa hukuman maka kemungkinan teori absolut dapat berlaku yaitu akan dihakimi oleh pihak yang telah dirugikannya. ${ }^{17}$ Oleh karena itu menurut Nigel Walker, teori ini lebih tepat disebut teori atau aliran reduktif (the reductive point of law) karena

\footnotetext{
${ }^{16}$ Putu Sekarwangi Saraswati, "Fungsi Pidana Dalam Menanggulangi Kejahatan”, Jurnal Advokasi Vol. 5 No.2 September 2015, hlm 143-144.

17 Imam Yazid, "Teori Pengenaan Sanksi Pelanggaran Hukum dan Relevansinya Terhadap Pelanggar Wajib Zakat di Indonesia”, Al Mashlahah Jurnal Hukum dan Pranata Sosial Islam, 2017, 243-244.
} 
dasar pembenaran pidana menurut teori ini ialah untuk mengurangi frekuensi kejahatan. $^{18}$

Konsumen berhak atas kompensasi atau ganti rugi terhadap penyampaian informasi yang tidak benar atau menyesatkan tentang kondisi dan jaminan barang termasuk penggunaannya dan memperdagangkan barang yang tidak sesuai dengan janji yang dinyatakan dalam iklan. Pengertian kerugian menurut oleh Yahya Harahap ialah "kerugian nyata" atau "fietelijke nadeel" yang ditimbulkan perbuatan wanprestasi ${ }^{19}$. Kerugian nyata ini ditentukan oleh suatu perbandingan keadaan yang tidak dilakukan oleh pihak debitur. Dengan demikian, besarnya jumlah ganti rugi sebesar jumlah yang "wajar" sesuai dengan besarnya nilai prestasi yang menjadi obyek perjanjian dibanding dengan keadaan yang menyebabkan timbulnya wanprestasi. Lebih lanjut Abdulkadir Muhammad menjelaskan bahwa Pasal 1243 KUHPerdata sampai dengan Pasal 1248 KUHPerdata merupakan pembatasan-pembatasan yang sifatnya sebagai perlindungan undang-undang terhadap debitur (dalam hal ini kosumen) dari perbuatan sewenangwenang pihak kreditur (pelaku usaha) sebagai akibat wanprestasi. ${ }^{20}$ Sedangkan kerugian yang timbul karena perbuatan melawan hukum sebagaimana diatur dalam Pasal 1365 KUHPerdata yang mengakibatkan kerugian (bagi konsumen) karena kesalahannya (pelaku usaha) harus mengganti kerugian.

\section{Tanggung Jawab Pelaku Usaha berkaitan dengan Penayangan iklan niaga yang menyesatkan yang menyesatkan Konsumen}

Konsep tanggung jawab dikemukakan oleh pencetus teori hukum murni yaitu Hans Kelsen yang berpendapat bahwa tanggung jawab berkaitan erat dengan kewajiban, tetapi tidak identik. Kewajiban tersebut muncul karena adanya aturan hukum yang mengatur dan memberikan kewajiban kepada subyek hukum. Subyek hukum yang dibebani kewajiban harus melaksanakan sebagai perintah dari aturan hukum yang berlaku. Akibat dari tidak dilaksanakannya kewajiban, maka akan menimbulkan reaksi yang berupa pengenaan sanksi. Sanksi ini merupakan tindakan paksa dari aturan atau ketentuan hukum agar kewajiban tersebut harus dilaksanakan dengan baik oleh subyek hukum. Lebih lanjut, menurut Hans Kelsen, subyek hukum yang dikenakan sanksi tersebut "bertanggung jawab" atau secara hukum bertanggung jawab atas pelanggaran $^{21}$ yang telah dilakukannya. Dengan demikian, tanggung jawab hukum harus mempunyai dasar atau landasan, yaitu hal yang menyebabkan timbulnya hak hukum bagi seorang untuk menuntut orang lain sekaligus berupa hal yang melahirkan

\footnotetext{
${ }^{18}$ E.Z. Leasa, "Penerapan Sanksi Pidana dan Sanksi Tindakan dalam Kebijakan Legislasi", Jurnal Sasi Vol. 16 No. 4 Bulan Oktober Desember 2010, hlm 53.

${ }^{19}$ M. Tjoanda, "Wujud Ganti Rugi Menurut Kitab Undang-Undang Hukum Perdata", Jurnal Sasi Vol. 16 No. 4 Bulan Oktober - Desember 2010, hlm 44.

${ }^{20}$ Ibid.

${ }^{21}$ Hans Kelsen, Pure Theory of Law, Terjemah, Raisul Muttaqien, Teori Hukum Murni: Dasar-Dasar Ilmu Hukum Normatif, Cetakan Keenam, Bandung: Penerbit Nusa Media, 2008, hlm. 136. Lihat juga Vina Akfa Dyani, "Pertanggungjawaban Hukum dan Perlindungan Hukum bagi Notaris dalam Membuat Party Acte", Jurnal Lex Renaissance No. 1 Vol. 2 Januari 2017: 162 - 176, hlm 166.
} 
kewajiban hukum orang lain untuk memberi pertanggungjawabannya. ${ }^{22}$ Prinsip-prinsip tanggung jawab dalam hukum dapat dibedakan sebagai berikut:

1. Prinsip Tanggung Jawab Berdasarkan Unsur Kesalahan(fault liability atau liability based on fault) ${ }^{23}$ adalah prinsip yang berlaku umum dalam hukum pidana dan perdata (1365 KUHPerdata) Prinsip ini menyatakan, seseorang baru dapat dimintakan pertanggungjawabannya secara hukum jika ada unsur kesalahan yang dilakukannya.

2. Prinsip Praduga Untuk Selalu Bertanggung Jawab ${ }^{24}$, yaitu tergugat selalu "dianggap" bertanggung jawab (presumption of liability principle), sampai dapat membuktikan bahwa tidak bersalah. Dalam prinsip ini, beban pembuktiannya ada pada tergugat berdasarkan beban pembuktian terbalik (omkering van bewijslast). Hal ini tidak sesuai dengan asas hukum praduga tidak bersalah (presumption of innocence) tetapi apabila diterapkan dalam sengketa konsumen tampak asas demikian cukup relevan, sehingga pihak yang berkewajiban untuk membuktikan kesalahan itu ada pada pihak pelaku usaha yang digugat ${ }^{25}$.

3. Prinsip Tanggung Jawab Mutlak (strict liability) ${ }^{26}$ yang sering diidentikkan dengan prinsip tanggung jawab absolut (absolute liability), tetapi ada pula para ahli yang membedakan kedua terminologi di atas. Strict liability adalah prinsip tanggung jawab yang menetapkan kesalahan tidak sebagai faktor yang menentukan. Namun ada pengecualian-pengecualian yang memungkinkan untuk dibebaskan dari tanggung jawab, misalnya pada keadaan force majeure. Sebaliknya absolute liability adalah prinsip tanggung jawab tanpa kesalahan dan tidak ada pengecualiannya.

4. Prinsip Tanggung Jawab karena pebuatan pihak lain (vicarious liability) yaitu Tanggung jawab yang dikenakan akibat perbuatan pihak lain yang berada dalam pengawasannya (Pasal 1367 KUHPerdata).

Bentuk tanggung jawab pelaku usaha dalam Undang-undang Perlindungan Konsumen mengandung materi yang berstruktur sebagai berikut: ${ }^{27}$

\section{Product Liability}

Tanggung jawab perdata secara langsung dari pelaku usaha atas kerugian yang dialami akibat mengkonsumsi produk yang dihasilkannya.

\section{Profesional Liability}

22 Titik Triwulan dan Shinta Febrian, Perlindungan Hukum bagi Pasien, Jakarta: Prestasi Pustaka, 2010, hlm 48. Lihat juga Quri Orchid, Tanggung Jawab Media Cetak Terhadap Penerbitan Iklan Yang Menyesatkan Konsumen, Program Pascasarjana Magister Ilmu Hukum Konsentrasi Hukum Perdata Universitas Hasanuddin Makassar, 2017, hlm 12.

${ }^{23}$ Shidarta, op.cit, hlm 73-79.

24 Ibid.

${ }^{25}$ https://sinta.unud.ac.id/uploads/dokumen_dir/55a096d81bd32165c62a810cfb889255.pdf diakses pada tang- gal 16 Desember 2020 pukul 22.00 WIB.

${ }^{26}$ Shidarta, op.cit, hlm 73-79.

27 Anthon Fathanudien, "Pertanggungjawaban Terhadap Konsumen Atas Iklan-Iklan Yang Menyesatkan Di Era Globalisasi”, Jurnal Unifikasi, ISSN 2354-5976 Vol. 2 No. 2 Juli 2015, hlm 43-44. 
Tanggung jawab perdata yang didasarkan pada tanggung jawab secara langsung atas dasar perjanjian kontrak dari pelaku usaha pemberi jasa atas kerugian yang dialami oleh konsumen akibat memanfaatkan jasa yang diberikannya.

\section{Contractual Liability}

Tanggung jawab perdata atas dasar perjanjian dari pelaku usaha baik terhadap barang maupun jasa yang dihasilkannya atas kerugian yang dialami konsumen akibat mengkonsumsi barang yang dihasilkannya atau memanfaatkan jasa yang diberikannya.

\section{Criminal Liability}

Tanggung jawab pidana dari pelaku usaha atas terganggunya keselamatan dan keamanan konsumen.

Hubungan hukum antara pelaku usaha periklanan yang meliputi pengiklan, biro iklan dan media iklan bersifat langsung dan tidak langsung. Bentuk pihak pemasang iklan langsung (direct) merupakan salah satu bentuk pemasangan iklan yang dilakukan oleh pengiklan yang secara langsung membuat dan menayangkan iklan sendiri di media cetak, ${ }^{28}$ berdasarkan perjanjian antara pengiklan dan media iklan. Pengiklan bertanggungjawab atas informasi yang benar tentang produk yang diberikan kepada Media iklan dan Media iklan harus memperhatikan ketepatan antara iklan yang ditayangkan dengan pesan iklan yang diberikan oleh pengiklan, karena itu media iklan bertanggung jawab terhadap iklan jika terjadi perubahan dalam penerbitan yang berbeda dari informasi asli yang telah ditetapkan oleh pengiklan menjadi iklan yang menyesatkan.

Penayangan iklan tidak langsung (indirect) merupakan bentuk pemasangan iklan yang dilakukan oleh biro iklan, sehingga pengiklan tidak membuat dan memasang iklan sendiri di media cetak tetapi menggunakan jasa biro iklan, ${ }^{29}$ karena itu yang melakukan kontraktual berkaitan dengan penayangan iklan adalah biro iklan dengan media iklan (cetak maupun elektronik), sehingga pembebanan tanggung jawab dibebankan kepada biro iklan sebagai pemasang iklan yang memberi materi iklan apabila terjadi perbedaan antara informasi iklan yang diberikan oleh pengiklan dengan iklan yang dibuat oleh biro iklan sehingga terjadi iklan yang menyesatkan. Sedangkan media iklan ikut bertanggung jawab, apabila tidak memeriksa kebenaran iklan atau minimal mempertimbangkan untuk tidak menayangkan iklan yang diduga menyesatkan sehingga bertentangan dengan kaidah hukum positif.

Apabila iklan yang ditayangkan atas permintaan pengiklan baik itu bentuknya maupun yang menyangkut isinya, sehingga biro iklan dan media yang mengiklankannya hanya bersifat pasif dalam arti mereka hanya membuat secara utuh sesuai dengan permintaan pengiklan, maka dalam hal ini yang bertanggung jawab secara penuh adalah pengiklan yang bersangkutan. Dalam, pengiklan dan media iklan bersifat pasif, sedangkan biro iklan yang mendesain bentuk termasuk isinya, maka yang bertanggung

${ }^{28}$ Quri Orchid, op.cit, hlm 82.

${ }^{29}$ Ibid. 
jawab adalah biro iklan yang bersangkutan. Apabila dalam mengiklankan suatu produk pengiklan dan biro iklan telah menetapkan bentuk dan isi iklan, tetapi dalam penayangannya terjadi perubahan, sehingga pada saat ditayangkan berbeda dengan yang sebenarnya, maka yang bertanggung jawab adalah media iklan yang bersangkutan. ${ }^{30}$ Dalam kaitan ini, teori the privity of contract menyatakan pelaku usaha mempunyai kewajiban untuk melindungi konsumen, tetapi hal itu baru dapat dilakukan jika telah terjalin suatu hubungan kontraktual. Pelaku usaha tidak dapat disalahkan diluar hal-hal yang diperjanjikan, sehingga konsumen dapat menggugat berdasarkan wanprestasi. Hal ini sesuai dengan ketentuan dalam Pasal 1340 KUHPerdta yang menyatakan tentang ruang lingkup berlakunya perjanjian hanyalah antara pihak-pihak yang membuat perjanjian saja. $^{31}$

Dengan demikian, iklan menyesatkan yang dapat merugikan konsumen merupakan tanggung jawab dari semua pihak yang terlibat dalam hubungan hukum terkait pembuatan iklan tersebut baik pengiklan, perusahaan iklan (biro iklan), dan media periklanan berdasarkan keterlibatan masing-masing pihak mulai dari penciptaan, pembuatan, sampai dengan penerbitan iklan. Pengiklan (pelaku usaha), bertanggung jawab atas seluruh informasi tentang produk dan jasa yang diiklankan, termasuk dalam memberi arahan dan batasan kepada biro iklan agar tidak terjadi janji yang berlebihan pada pesan-pesan iklan. Namun, bebas untuk bertanggung jawab apabila biro iklan mendesain bentuk dan isi iklan tanpa persetujuannya dan media cetak menerbitkan iklan yang berbeda dengan yang sebenarnya (termasik iklan yang menyesatkan). Biro iklan, bertanggung jawab apabila mendesain bentuk dan isinya iklan tanpa pengetahuan dan persetujuan pengiklan, dan ikut bertanggung jawab dengan pengiklan apabila tidak mempertimbangkan dampak kreativitas iklan termasuk ketepatan penggunaan unsur persuasif dalam menerjemahkan bahasa dan gambar iklan. Media Cetak, bertanggung jawab apabila terjadi perbedaan dengan dan isi iklan yang telah ditetapkan baik dari pengiklan maupun biro iklan, dan apabila tidak meneliti kebenaran iklan atau mampu memilah dan memilih bentuk dan pesan-pesan periklanan yang sesuai dengan Etika Pariwara Periklanan Indonesia dan profil khalayak sasarannya berdasarkan kewajiban hukumnya ${ }^{32}$

Prinsip tanggung jawab pelaku usaha (pengiklan, biro iklan, dan media iklan) berkaitan dengan iklan yang menyesatkan tercantum dalam Pasal 20 jis Pasal 22, Pasal 28 UUPK. Prinsip pertanggungjawaban tersebut adalah strict liability atau tanggung jawab secara langsung sebagaimana diatur dalam Pasal 20 UUPK" Pelaku usaha periklanan bertanggung jawab atas iklan yang diproduksi dan segala akibat yang ditimbulkan oleh iklan tersebut". Sedangkan bentuk tanggungjawabnya adalah product

\footnotetext{
${ }^{30}$ I Made Surya Kartika A.A Sagung Wiratni Darmadi, "Tanggung Jawab Pelaku Usaha Periklanan dalam memberikan Informasi yang Lengkap dan Benar", 2016, hlm 4. https://ojs. unud.ac.id/index. php/kerthasemaya/ article/view/13381/9072 diakses pada tanggal 20 Desember 2020 pukul 19.00 WIB.

${ }^{31}$ Shidarta, Hukum Perlindungan Konsumen Indonesia, Edisi Revisi, Jakarta: Gramedia Widiasarana Indonesia, 2016, hlm 6.

${ }^{32}$ Yusuf Sophie, Pelaku Usaha, Konsumen, dan Tindak Pidana Korporasi, Bogor: Ghalia Indonesia, 2016, hlm 145 .
} 
liability yaitu tanggung jawab terhadap produk yang ditayangkan melalui iklan menyesatkan (Pasal 9 UUPK) dan tanggung jawab berdasarkan perjanjian (contractual liability) sebagaimana tercantum dalam (Pasal 10, 11, 12, 13, dan 17 UUPK), atau profesional liability (biro iklan) dan media iklan atau kedua-duanya tergantung keterlibatannya dalam pembuatan iklan.

Pembuktian terhadap ada tidaknya unsur kesalahan dalam kasus pidana berkaitan dengan iklan yang diproduksi dan segala akibat yang ditimbulkan oleh iklan tersebut merupakan beban dan tanggung jawab pelaku usaha tanpa menutup kemungkinan bagi jaksa untuk melakukan pembuktian. Hal ini berarti berkaitan dengan kasus pidana, pelanggaran terhadap UUPK khususnya iklan yang menyesatkan merupakan Pembuktian Terbalik artinya suatu jenis pembuktian yang berbeda dengan hukum acara pidana yang diatur dalam KUHAP. Jenis pembuktian ini mewajibkan Terdakwa (pelaku usaha) untuk membuktikan bahwa dirinya tidak bersalah atau membuktikan secara negatif (sebaliknya) terhadap dakwaan Penuntut Umum. Walaupun Terdakwa dibebani beban pembuktian tetapi tidak menghapuskan kewajiban Penuntut Umum Pula sesuai dengan Pasal 66 KUHAP yaitu juga untuk membuktikan mengingat sifat "berimbang" dari pembuktian terbalik di Indonesia. ${ }^{33}$

Pembuktian terhadap ada tidaknya unsur kesalahan berkaitan dengan iklan yang menyesatkan dalam gugatan ganti rugi merupakan beban dan tanggung jawab pelaku usaha berdasarkan prinsip tergugat selalu "dianggap" bertanggung jawab (presumption of liability principle), sampai dapat membuktikan bahwa pelaku usaha tidak bersalah. Ketentuan ini sesuai dengan prinsip keadilan dalam arti "meletakan sesuatu pada tempatnya" 34 karena apabila konsumen harus membuktikan kesalahan pelaku usaha berkaitkan dengan iklan menyesatkan mengalami kesulitan. Pembuktian penting dalam penyelesaian sengketa (berlaku untuk semua sengketa konsumen) termasuk iklan yang menyesatkan tercantum dalam Pasal 45 ayat (2) UUPK" Penyelesaian sengketa konsumen dapat ditempuh melalui pengadilan atau di luar pengadilan berdasarkan pilihan sukarela para pihak yang bersengketa." Penyelesaian sengketa melalui pengadilan (dilingkungan peradilan umum) dilakukan berdasarkan gugatan oleh pihak yang merasa dirugikan dengan adanya iklan yang menyesatkan.

Penyelesaian melalui pengadilan atau peradilan umum membutuhkan biaya yang besar dan waktu yang lama. Selain itu penyelesaian melaui pengadilan juga dapat menyebabkan kerenggangan hubungan antara pelaku usaha dan konsumen. ${ }^{35}$ Karena itu, dapat juga dilakukan penyelesaian sengketa diluar pengadilan dapat dilakukan dengan damai yaitu penyelesaian sengketa antara pihak dengan atau tanpa kuasa/pendampingan bagi masing-masing pihak. Cara damai dapat ditempuh dengan cara perundingan secara

\footnotetext{
${ }^{33}$ M. Edo Rezawan Prasetia, et al, "Sistem Pembuktian Terbalik Dalam Pembuktian Perkara Gratifikasi”, Jurnal Verstek Vol. 2 No. 2, Bagian Hukum Acara Universitas Sebelas Maret, 2014, hlm 186.

${ }^{34}$ Ana Suheri, "Wujud Keadilan Dalam Masyarakat Ditinjau Dari Perspektif Hukum Nasional”, Jurnal Morality, Volume 4 Nomor 1, Juni 2018, hlm 65.

${ }^{35}$ Elia Wuria Dewi, Hukum Perlindungan Konsumen, Yogyakarta: Graha Ilmu, 2015, hlm 135.
} 
musyawarah dan/atau mufakat antara pihak yang bersangkutan. ${ }^{36}$ Jika cara damai tidak dapat dilakukan, maka sengketa diselesaikan melalui Badan Penyelesaian Sengketa Konsumen berdasarkan Keputusan Menteri Perindustrian dan Perdagangan Nomor 350/MPP/Kep/12/2001 ${ }^{37}$.

Tidak semua sengketa konsumen layak diajukan ke pengadilan karena jumlah nominal tersebut sangat kecil, sedangkan untuk beracara membutuhkan biaya yang besar serta jangka waktu penyelesaian sengketa yang sangat lambat. ${ }^{38}$ Beberapa kasus iklan menyesatkan yang masuk ke pengadilan pada umumnya menyangkut kerugian konsumen dalam jumlah nominal yang besar dan diajukan secara berkelompok (class action) atau dengan mempergunakan mekanisme gugatan organisasi non pemerintah atau Lembaga swadaya masyarakat yang memiliki legal standing. Hal tersebut dimungkinkan berdasarkan ketentuan Pasal 46 ayat (2) jo. Pasal 46 ayat (1) UUPK dan hal tersebut lebih efektif untuk menyiasati biaya berperkara di pengadilan yang mahal serta dapat mewakili anggota kelompok. ${ }^{39}$

Gugatan yang dilakukan oleh konsumen berkaitan dengan iklan yang menyesatkan baik melalui pengadilan maupun diluar pengadilan merupakan perwujudan pelindungan melalui regulasi berkaitan dengan hak kosumen atas informasi yang benar. Bentuk perlindungan hukum yang erat kaitannya dengan aspek keadilan, karena pada hakikatnya tujuan hukum konvensional adalah mencapai keadilan, sehingga perlindungan hukum merupakan salah satu medium untuk menegakkan keadilan di bidang ekonomi, ${ }^{40}$ selain kepastian hukum dan kemanfaatan dalam proses pelaksanaan atau penegakan hukumnya. Sedangkan tujuan hukum modern adalah hukum merupakan sarana perubahan sosial masyarakat (khususnya pelaku usaha) baik sebagai social control maupun social engineering agar tidak membuat iklan yang menyesatkan.

\section{PENUTUP}

Larangan bagi Pelaku Usaha terhadap kualifikasi Iklan yang menyesatkan dihubungkan dengan hak konsumen yang diatur dalam ketentuan Pasal 9 UUPK termasuk klasifikasi false advertising karena representasi tentang fakta dalam iklan adalah salah, kriteria deceptive yaitu iklan yang dapat memperdaya konsumen karena akan mengira bahwa iklan tersebut benar padahal "seolah olah" yang bertipe iklan fraudulent advertising yaitu iklan yang tidak dapat dipercaya (straight forwardlie). Pasal 10 dan Pasal 12 UUPK merupakan klasifikasi iklan false advertising, bentuk iklan termasuk kriteria

\footnotetext{
${ }^{36}$ Dedi Harianto, Perlindungan Hukum Bagi Konsumen Terhadap Iklan Yang $\quad$ Menyesatkan, Bogor: Ghalia Indonesia, 2010, hlm 240.

37 Selengkapnya, Lihat Tulus Siambaton dan Yosua Lorenzo Tarigan, "Bentuk Perlindungan Hukum Terhadap Konsumen Akibat Iklan Yang Menyesatkan Pada Media Cetak", Jurnal Visi Ilmu Sosial dan Humaniora (VISH), Volume: 01, No 02 Desember 2020(30-41), hlm 35-38.

${ }^{38}$ Harish Wien Saputra, "Perlindungan Hukum Bagi Konsumen Terhadap Iklan Yang Menyesatkan (Studi Kasus pada Produk Kangen Water)", Skripsi, Program Studi S1 Ilmu Hukum Universitas Islam Indonesia Yogyakarta, 2018, hlm 99.

${ }^{39}$ Dedi Harianto, op.cit, hlm 240.

${ }^{40}$ Hilda Hilmiah Dimyati, "Perlindungan Hukum Bagi Investor Dalam Pasar Modal", Jurnal Cita Hukum, Vol. 2, No. 2, 2014, hlm 342- 343.
} 
iklan yang tidak benar atau menyesatkan (misleading) karena menyebutkan adanya sesuatu yang sebenarnya tidak ada atau sebaliknya, tipe iklan fraudulent advertising, iklan yang tidak dapat dipercaya (straight forwardlie). Pasal 13 UUPK termasuk klasifikasi false advertising karena representasi tentang fakta dalam iklan adalah salah, tipe iklan fraudulent advertising, iklan yang tidak dapat dipercaya (straight forwardlie), bentuk iklan pancingan (bait and switch advertising), dan kriteria iklan yang mengelabui konsumen (misleading). Pasal 17 ayat (1) UUPK termasuk klasifikasi iklan yang false advertising, kriteria mengelabui konsumen (misleading) dan deceptive karena iklan yang dapat memperdaya konsumen dengan tipe fraudulent advertising iklan yang tidak dapat dipercaya (straight forwardlie).

Lebih lanjut, prinsip pertanggungjawaban pelaku usaha sesuai Pasal 20 UUPK adalah strict liability atau tanggung jawab secara langsung dan vicarious liability. Sedangkan berkaitan dengan Pasal 9 UUPK bentuk tanggungjawabnya adalah product liability dan contractual liability (Pasal 10, 11, 12, 13, dan 17 UUPK), atau profesional liability bagi biro iklan dan media iklan atau kedua-duanya tergantung keterlibatannya dalam pembuatan iklan mulai penciptaan kreasi, pembuatan, dan penayangan iklan serta tidak menutup kemungkinan pelaku usaha dikenakan sanksi pidana berdasarkan prinsip tanggung jawab presumption of liability principle dan bentuk tanggung jawab criminal liability.

Artikel ini menilai perlunya dibuat peraturan perundangan-undangan dibawah Undang-Undang seperti Peraturan Pemerintah atau Peraturan Menteri yang mengatur tentang iklan niaga termasuk di dalamnya kualifikasi iklan niaga yang menyesatkan. Selain itu, perlu dirinci secara tegas kualifikasi pelaku usaha periklanan yang terdiri dari pengiklan, biro iklan, dan media iklan serta aturan mengenai ukuran penentuan tanggung jawab hukum bagi masing-masing pelaku usaha periklanan tersebut dalam peraturan perundang-undangan yang nanti dibuat.

\section{DAFTAR PUSTAKA}

\section{Buku}

Ahmadi Miru dan Sutarman Yodo, Hukum Perlindungan Konsumen, Jakarta: PT. Raja Grafindo Persada, 2008.

Ali Achmad, Menguak Teori Hukum (Legal Theory) \& Teori Peradilan (Judicialprudence), 2009.

Celina Tri Kristiyanti, Hukum Perlindungan Konsumen, Jakarta: Sinar Grafika, 2011.

Dewi Elia Wuria, Hukum Perlindungan Konsumen, Graha Ilmu, Yogyakarta: Graha Ilmu, 2015.

Dedi Harianto, Perlindungan Hukum Bagi Konsumen Terhadap Iklan Yang Menyesatkan, Bogor: Ghalia Indonesia, 2010.

Elia Wuria Dewi, Hukum Perlindungan Konsumen, Yogyakarta: Graha Ilmu, 2015.

Hans Kelsen, Pure Theory of Law, Terjemah, Raisul Muttaqien, Teori Hukum Murni: Dasar-Dasar Ilmu Hukum Normatif, Cetakan Keenam, Bandung: Penerbit Nusa Media, 2008. 
Dialogia luridica: Jurnal Hukum Bisnis dan Investasi

Volume 12, Nomor 2, April 2021

Shidarta, Hukum Perlindungan Konsumen Indonesia, Edisi Revisi, Jakarta: Gramedia Widiasarana Indonesia, 2016.

Taufik H Simatupang, Aspek Hukum Periklanan dalam Perspektif Perlindungan Konsumen, Bandung: Citra Aditya Bakti, 2014.

Titik Triwulan dan Shinta Febrian, Perlindungan Hukum bagi Pasien, Jakarta: Prestasi Pustaka, 2010.

Yusuf Sophie, Pelaku Usaha, Konsumen, dan Tindak Pidana Korporasi, Bogor: Ghalia Indonesia, 2016.

\section{Jurnal}

Aghia Khumaesi Suud, "Analisis Perlindungan Hukum Bagi Konsumen Terhadap Iklan Barang atau Jasa Online yang Menyesatkan”, Pandecta, Volume 14. Number 2. December 2019.

Ana Suheri, "Wujud Keadilan Dalam Masyarakat Ditinjau Dari Perspektif Hukum Nasional", Jurnal Morality, Volume 4 Nomor 1, Juni, 2018.

Anthon Fathanudien, "Pertanggungjawaban Terhadap Konsumen Atas Iklan-Iklan Yang Menyesatkan Di Era Globalisasi”, Jurnal Unifikasi, ISSN 2354-5976 Vol. 2 No. 2 Juli, 2015.

Ashadi L Diab, "Peranan Hukum Sebagai Social Control, Social Engineering dan Social Welfare”, Jurnal Al- 'Adl, Vol. 7 No. 2, Juli, 2014.

Dedi Harianto, "Standar Penentuan Informasi Iklan Menyesatkan", Jurnal Equality, Vol. 13 No. 1 Februari, 2008.

E.Z Leasa, "Penerapan Sanksi Pidana dan Sanksi Tindakan dalam Kebijakan Legislasi”, Jurnal Sasi vol. 16 No. 4 Bulan Oktober Desember, 2010.

Henni Muchtar, "Analisis Yuridis Normatif Sinkronisasi Peraturan Daerah Dengan Hak Asasi Manusia", Jurnal Humanus Vol. XIV No.1, 2015.

Hilda Hilmiah Dimyati, "Perlindungan Hukum Bagi Investor Dalam Pasar Modal", Jurnal Cita Hukum, Vol. 2, No. 2, 2014.

Indra Rahmatullah, "Iklan Menyesatkan (Deceptive Advertisement) Dalam Hukum Perlindungan Konsumen", ADALAH, Buletin Hukum dan Keadilan, Volume 2 Nomor 7b, 2018.

Imam Yazid, "Teori Pengenaan Sanksi Pelanggaran Hukum dan Relevansinya Terhadap Pelanggar Wajib Zakat di Indonesia|, Al Mashlahah Jurnal Hukum dan Pranata Sosial Islam, 2017.

M. Edo Rezawan Prasetia, et al. "Sistem Pembuktian Terbalik Dalam Pembuktian Perkara Gratifikasi”, Jurnal Verstek Vol. 2 No. 2, 2014.

M Tjoanda, "Wujud Ganti Rugi Menurut Kitab Undang-Undang Hukum Perdata", Jurnal Sasi, Vol. 16 No. 4 Bulan Oktober - Desember, 2010.

Putu Sekarwangi Saraswati, "Fungsi Pidana Dalam Menanggulangi Kejahatan", Jurnal Advokasi Vol. 5 No.2 September 2015. 
Tulus Siambaton dan Yosua Lorenzo Tarigan, "Bentuk Perlindungan Hukum Terhadap Konsumen Akibat Iklan Yang Menyesatkan Pada Media Cetak", Jurnal Visi Ilmu Sosial dan Humaniora (VISH), Volume: 01, No 02 Desember 2020.

Vina Akfa Dyani, "Pertanggungjawaban Hukum dan Perlindungan Hukum bagi Notaris dalam Membuat Party Acte”, Jurnal Lex Renaissance No. 1 Vol. 2 Januari 2017.

\section{Peraturan Perundang-undangan}

Undang-Undang Republik Indonesia Nomor 9 Tahun 1999 tentang Pelindungan Konsumen.

Undang-Undang Republik Indonesia Nomor 32 Tahun 2002 tentang Penyiaran.

Undang-Undang Republik Indonesia Nomor 33 Tahun 2009 tentang Perfilman.

Peraturan Pemerintah Nomor 69 Tahun 1999 Tentang Label dan Iklan Pangan.

\section{Tesis, Skripsi, Karya Tulis dan Terbitan Lainnya}

Adde Riyatna Harahap, Perlindungan Hukum Bagi Konsumen Akibat Iklan Yang Menyesatkan, Skripsi, Fakultas Hukum Universitas Muhammadiyah Sumatera Utara Medan, 2019.

Etika Pariwara Indonesia (EPI), 2020.

Harish Wien Saputra, Perlindungan Hukum Bagi Konsumen Terhadap Iklan Yang Menyesatkan (Studi Kasus pada Produk Kangen Water), Skripsi, Program Studi S1 Ilmu Hukum Universitas Islam Indonesia Yogyakarta, 2018.

Nenny Febriyanti, Analisis Yuridis Terhadap Iklan Menyesatkan Pada Produk Multivitamin Dikaitkan Dengan Undang-Undang Perlindungan Konsumen Dan KEPMENKES No: 386/MEN.KES/ SK/IV/1994 (Studi Kasus: Iklan Multivitamin $X)$, Fakultas Hukum Universitas Indonesia, 2018.

Quri Orchid, Tanggung Jawab Media Cetak Terhadap Penerbitan Iklan Yang Menyesatkan Konsumen (Print Media Liability for Advertisement Publishing Misleading Consumers). Program Pascasarjana Magister Ilmu Hukum Konsentrasi Hukum Perdata Universitas Hasanuddin Makassar, 2017.

\section{Pranalar Luar}

Herlina Butar Butar (ed :Widiyabuana Slay) Waspadai Iklan Extra Joss yang Menyesatkan, Tribunnews.com, https:// www.tribunnews.com/tribunners/2011/06/30/waspadai-iklan-extra-joss-yangmenyesatkan, diakses pada tanggal 13 Desember 2020 pukul 19.00 WIB.

http://download.garuda. ristekdikti. go.id/ article.php?article = 16672\&val= 5918\&title $=$ Iklan\%20 Menyesatkan \%20Deceptive\%20 Advertisement\% 20\%20Dalam\% 20Hukum\%20Perlindungan\%20Konsumen, diakses pada tanggal 14 Desember 2020 pukul 20.00 WIB.

http://e-journal.uajy.ac.id/ 3445/3/ 2 EM15140. Pdf, diakses pada tanggal 16 Desember 2020 pukul 21.00 WIB. 
https://sinta.unud.ac.id/ uploads/ dokumen_dir/ 55a096d81bd32165 c62a 810cfb889255.pdf diakses pada tanggal 16 Desember 2020 pukul 20.00 WIB.

http://repository.untag-sby.ac.id/ 1560/10/BAB\% 20III.pdf diakses pada tanggal 18 Desember 2020 pukul 21.00 WIB.

I Made Surya Kartika \& A.A Sagung Wiratni Darmadi (2016). Tanggung Jawab Pelaku Usaha Periklanan dalam memberikan Informasi yang Lengkap dan Benar. https://ojs. unud.ac.id/index.php/kerthasemaya/article/view/13381/9072, diakses pada tanggal 20 Desember 2020 pukul 19.00 WIB.

Paramita I Gusti Ayu Indra Dewi Dyah Pradnya dan Desak Putu Dewi Kasih. (2014), https://ojs.unud.ac.id/ index.php/ kerthasemaya/article/download/19803/13 Journal Ratu Adil, diakses pada tanggal 23 Desember 2020 pukul 19.30 WIB. www.FTC.Gov, diakses pada tanggal 2 Desember 2020 pukul 19.00 WIB. 